Article

\title{
Surface Properties of Pine Scrimber Panels with Varying Density
}

\author{
Jinguang Wei ${ }^{1}$, Qiuqin Lin ${ }^{1}$, Yahui Zhang ${ }^{1}$, Wenji Yu ${ }^{1, *}$, Chung-Yun Hse ${ }^{2}$ and Todd Shupe ${ }^{3}$ \\ 1 Scrimber Engineering and Technology Research Center of State Forestry Administration, Research Institute \\ of Wood Industry, Chinese Academy of Forestry, Beijing 100091, China; weijg@caf.ac.cn (J.W.); \\ qqlin@caf.ac.cn (Q.L.); zhangyahui@caf.ac.cn (Y.Z.) \\ 2 Southern Research Station, USDA Forest Service, Pineville, LA 71360, USA; chse@fs.fed.us \\ 3 Wood Science Consulting, LLC., Baton Rouge, LA 70816, USA; tfshupe@gmail.com \\ * Correspondence: yuwenji@caf.ac.cn; Tel.: +86-10-62889427
}

Received: 2 May 2019; Accepted: 18 June 2019; Published: 20 June 2019

\begin{abstract}
Coating quality for scrimber products against exterior conditions is largely dependent on the surface properties. The wettability, morphology, and chemical composition of pine scrimber surfaces were investigated to better understand the surface properties. The scrimber was found to be a hydrophilic material because the water contact angles were less than $90^{\circ}$. The panels with a density of $1.20 \mathrm{~g} / \mathrm{cm}^{3}$ had the largest angle change rate $(k=0.212)$. As the panel density increased, the instantaneous contact angle of each test liquid (i.e., water, formamide, and diiodomethane) on the panels decreased, and so did surface free energy. Panels with higher density showed lower surface roughness. Surface roughness across the wood grain was greater than that along the grain. SEM observations showed the high-density panels had a smoother surface with fewer irregular grooves in comparison with the low-density panels. X-ray photoelectron spectroscopy (XPS) analysis indicated that more unoxygenated groups appeared on the surface of high-density panels.
\end{abstract}

Keywords: scrimber; density; wettability; roughness; SEM; XPS

\section{Introduction}

Scrimber is a reconsolidated wood-based panel product, which was invented by Coleman in 1975 [1]. The manufacturing process crushes small diameter pine wood into interconnected long strands with a scrimming machine, and then assembles the strands into a panel with a thermoset adhesive [2]. This process can utilize more than $85 \%$ of the average pine log [3], and can be applied to a wide range of species [4]. However, one drawback is unevenness in size of the strands, which can lead to panel density variation, surface roughness, and poor dimensional stability such as curl, deformation, and swelling. Yu et al. improved the process method [5]. Round wood was first peeled into thick veneers, and then split into oriented wood fiber mats (OWFMs), followed by assembling with a phenol-formaldehyde resin. Compared to the traditional process, this method has very uniform fiber strands, which significantly improves the density uniformity and surface quality [6]. Moreover, excellent dimensional stability and mechanical performance are also achieved [7]. These materials are very promising alternatives to existing wood-based structural panels.

Scrimbers are coated with a coating for aesthetical appearance, and long-term utilization against weather, abrasion, and biological attack [8-10]. Their surface properties exhibit high affinity to the bonding quality between the coating and panel surface [11]. Wetting behavior is an important factor [12]. Regardless of what coating is used, good wettability contributes to better mechanical interlocking, molecular-level interactions, and secondary force interactions between the coating film and the wood 
surface [13]. For example, if a hydrophobic coating cured before it completely wetted the target surface, a weak boundary layer with entrapped air would occur and result in poor bonding [14].

Wettability can be assessed by surface contact angles [15]. The smaller the contact angle, the better the surface wettability and vice versa [16]. The contact angles on the surface of wood materials are governed by surface geometry and chemistry $[17,18]$. Surface roughness has a great influence on contact angle values. Surface roughness causes a hydrophilic surface to be more hydrophilic, and a hydrophobic surface to be more hydrophobic $[19,20]$. The surface of natural wood, for example, is hydrophilic, and high surface roughness creates a more hydrophilic surface [21]. Apart from surface machining (e.g., sawing, planning, and sanding) [22], roughness is closely related to panel density [23]. Bao et al. [24] reported that the low-density compreg had high surface roughness while the high-density compreg had low roughness. The contact angles also are affected by wood surface chemistry, which is greatly involved with the molecular interaction between a liquid and the wood surface [25]. The restructuration and exudation of hydrophilic extractives decreases wettability [26], while more hydrophilic groups from cellulose and hemicellulose on the surface increase wettability [27].

In this study, the surface contact angles of scrimbers with various panel densities were measured to investigate their wettability. Their surface roughness, morphology, and chemistry were also assessed. The objective of this study was to better understand the surface properties of pine scrimber and provide valuable information for scrimber coating.

\section{Materials and Methods}

\subsection{Materials}

Radiata pine (Pinus radiata D. Don) was purchased from Linyi Jinshan Wood Co., Ltd. (Linyi, China). Phenol-formaldehyde (PF) resin with a solid content of $47.49 \%$, viscosity of $41 \mathrm{mPa} \cdot \mathrm{s}$ at $25^{\circ} \mathrm{C}$, and a $\mathrm{pH}$ of $\sim 10$ was obtained from Dynea Guangdong Co., Ltd., Zhaoqing, China. Formamide and diiodomethane were of analytical grade and other chemicals used were of reagent grade and were purchased from Aldrich Chemical (Shanghai, China) Co., Ltd.

\subsection{Methods}

\subsubsection{Scrimber Fabrication}

Oriented wood fiber mats were prepared using pine logs as a raw material [5], and the scrimbers were obtained through laminating OWFMs into a bulk panel under hot pressing. In brief, the log was softened in boiling water and then peeled into veneers with a 6-mm thickness using a spindleless veneer lathe (Xuanjin, Linyi, China). The veneers were split along the wood grain direction into OWFMs by a fluffing machine. The mats were dried in an oven at $70{ }^{\circ} \mathrm{C}$ until the moisture content was approximately $10 \%$. The dried mats were impregnated with dilute PF resin (solids content of $10 \mathrm{wt} . \%$ ) and the weight gain was $13 \mathrm{wt} . \%$ based on the oven dried weight of the mats. The wet mats were dried at $40^{\circ} \mathrm{C}$ until a moisture content of $\sim 11 \%$ was reached. A certain weight of the dried mats was assembled along the grain direction in the mold. The hot pressing was conducted at $145^{\circ} \mathrm{C}$ for $30 \mathrm{~min}$ on a Model 3856 thermocompressor (CARVER, Wabash, IN, USA) to obtain a scrimber panel $\left(300 \times 100 \times 20 \mathrm{~mm}^{3}\right)$. By changing the mat weight, a series of panels were obtained with various densities (i.e., $0.80,1.01,1.20$ and $1.39 \mathrm{~g} / \mathrm{cm}^{3}$ ). Prior to testing, the panels were conditioned in a chamber at $65 \pm 5 \%$ relative humidity (RH) at $20 \pm 2{ }^{\circ} \mathrm{C}$ for two weeks.

\subsubsection{Sanding Treatment}

A MM491GL wide-belt sander (LUXTER, Haining, China) equipped with a 180-grit aluminum oxide sandpaper was used to sand the panels. The belt moved along the wood grain and a constant pressure between the platen and panel was maintained. The feed speed was $10 \mathrm{~m} / \mathrm{min}$ and approximately 
$1.0 \mathrm{~mm}$ of thickness was removed. The surface was pneumatically cleaned by a $0.75 \mathrm{LE}-835 \mathrm{C}$ air compressor (Hitachi, Tokyo, Japan) to remove wood particles.

\subsubsection{Surface Wettability}

The contact angles of three liquids (i.e., water, formamide, and diiodomethane) were measured by the sessile drop method. The measurements were carried out on a JC2000D contact angle analyzer (Xi'an Yima Opto-electrical Technology Co., Ltd., Xi'an, China) at a constant temperature of $20^{\circ} \mathrm{C}$ and at an $\mathrm{RH}$ of $40 \%-50 \%$. Five specimens were sampled for each group with the same density, and at least five measurements were carried out for each specimen. The contact angle change rate ( $k$ value) of water was calculated by the model developed by Shi and Gardner [28]. The Lifshitze-van der Waals/acid-base (LW-AB) approach was used to calculate the total surface free energy $\gamma_{s}$, dispersive (or Lifshitz-van der Waals) component $\gamma_{s}^{L W}$, polar (or Lewis acid-base) component $\gamma_{s}^{A B}$, electron acceptor (or Lewis acid) component $\gamma_{s}^{+}$, and electron donor (or Lewis base) component $\gamma_{s}^{-}$[29].

\subsubsection{Determination of Surface Roughness}

Roughness measurements were carried out on a TIME 3230 roughometer (Beijing Time High Technology Co., Ltd., Beijing, China) equipped with a metal probe. Each surface of $280 \times 100 \mathrm{~mm}^{2}$ was scanned at a speed of $0.5 \mathrm{~mm} / \mathrm{s}$ in two directions: Parallel and perpendicular to the wood grain. A Gaussian filter with a cutoff wavelength of $0.8 \mathrm{~mm}$ was employed to transform the data. Mean surface roughness $(R a)$ was calculated according to ISO 4287 (1997) [24].

\subsubsection{Surface Observation}

Surface micrographs were taken from representative sanded surfaces with a S3400 scanning electron microscope (SEM) (Hitachi, Tokyo, Japan) at an accelerating voltage of $5.0 \mathrm{kV}$. The sample surfaces were sputter-coated with a thin layer of gold prior to observations.

\subsubsection{X-ray Photoelectron Spectroscopy (XPS)}

Surface elements were measured on an AXIS Ultra spectrometer (Kratos Analytical Ltd., Manchester, UK) with a monochromatic Al-K $\alpha$ X-ray source $(\lambda=1486.6 \mathrm{eV})$. The spectra covering a binding energy range of $0-1100 \mathrm{eV}$ was collected at a pass energy of $100 \mathrm{eV}$ and resolution of $1.00 \mathrm{eV} / \mathrm{step}$. The high-resolution spectra of $\mathrm{C} 1 \mathrm{~s}$ were recorded at a pass energy of $20 \mathrm{eV}$ and a resolution of $0.05 \mathrm{eV} / \mathrm{step}$. Gaussian peak profiles were used for spectral deconvolution of C1s spectra, and quantitative measurements of binding energy and atomic concentration [30].

\section{Results}

\subsection{Surface Wettability}

The time dependence of the contact angels of water on the scrimber surfaces is presented in Figure 1. The contact angle on each panel was less than $90^{\circ}$, indicating that the surfaces were well wetted by water. The contact angles decreased on the scrimber surface with time. The contact angles on the high-density scrimber were higher than on the low-density panel, suggesting that the surface of low-density scrimber had better wettability. The $k$ value represents how fast the liquid spreads and penetrates into the porous structure of the wood materials [31]. As shown in Figure 1, the $k$ value increased from 0.154 to 0.212 as the panel density changed from 0.80 to $1.20 \mathrm{~g} / \mathrm{cm}^{3}$. When the density was $1.39 \mathrm{~g} / \mathrm{cm}^{3}$, the value dropped to 0.163 . These indicated that scrimber panels with a density of $1.20 \mathrm{~g} / \mathrm{cm}^{3}$ allowed water to penetrate and spread faster than other panel density levels. 


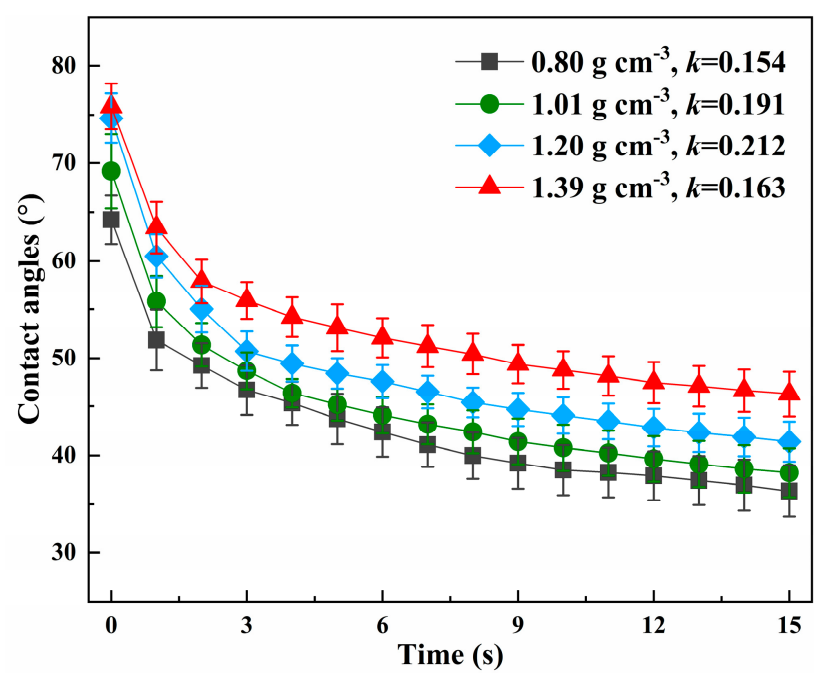

Figure 1. Contact angles of water as a function of time for scrimbers with various densities.

Apart from water, formamide and diiodomethane had changing contact angles as the panel density varied (see Figure 2). The greater the panel density, the larger the contact angles for all test liquids. Under the same panel density, water had the largest contact angle followed by diiodomethane. The smallest contact angle belonged to formamide, indicating that formamide had the best capacity for wetting. These differences mainly arose from the acidic-basic nature and the viscosity of the test liquids. The wood surface is acidic and formamide is alkaline [32]. The strong acid-base interaction between them reduced the interfacial free energy, which made the formamide quickly spread and penetrate the wood surface [22]. Therefore, lower contact angels were observed with formamide in comparison with that of water and diiodomethane.

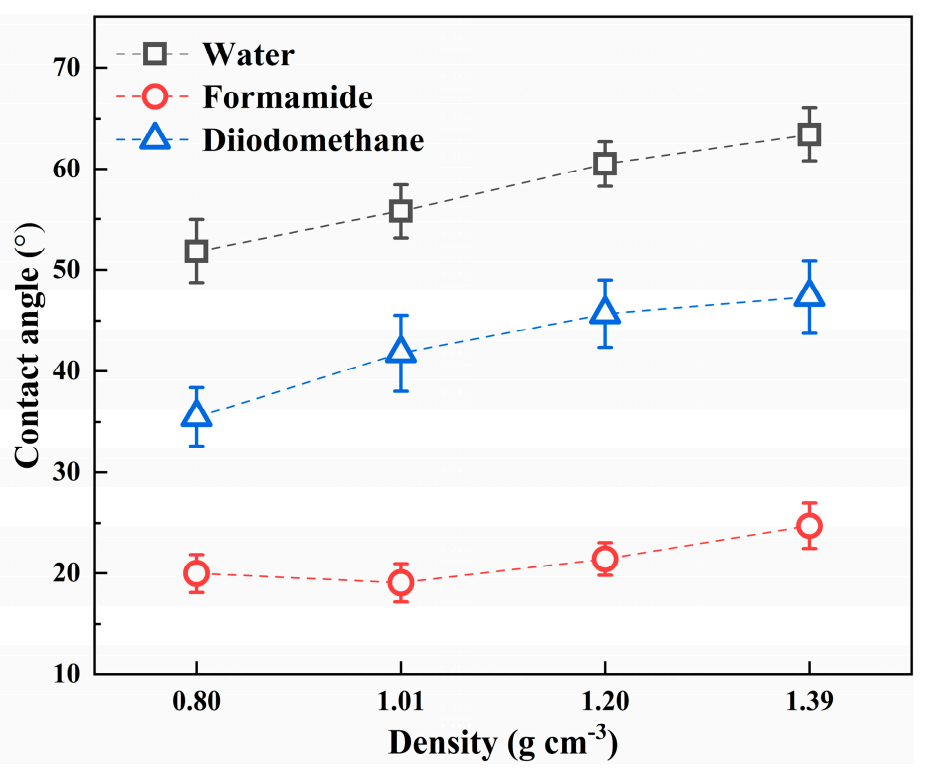

Figure 2. Contact angles of three liquids at one second on the scrimber surfaces.

Surface free energy is a critical parameter of wetting behavior, and it reflects the intermolecular force between a liquid and a solid $[27,33,34]$. Due to the rapid spread time of formamide droplets in contact with the scrimber surface and the instability of the droplets at the initial stage $(t=0)$, the contact angles at one second were used to calculate the surface energy. The results are listed in Table 1. It was found that the total surface free energy $\gamma_{S}$ exhibited a declining trend with an increase in panel density. This was mainly attributed to the reduction of the dispersive components $\gamma_{S}^{L W}$. The dispersive 
component was associated with the presence and concentration of free hydroxyl groups exposed on the surface of lignocellulosic materials [35]. The high-density panels had fewer hydroxyl groups on the surface due to surface inactivation upon hot-pressing [36]. In addition, there was a slight reduction of polar components $\gamma_{S}^{A B}$, which mainly stemmed from the decreasing electron donor component $\gamma_{S}^{-}$. This reduction of all components resulted in all high-density panels having lower wettability, which was consistent with the findings for hybrid poplar compreg by Bao et al. [24].

Table 1. Surface free energy of scrimbers with varying density.

\begin{tabular}{cccccc}
\hline \multirow{2}{*}{$\begin{array}{c}\text { Density } \\
\left(\mathrm{g} / \mathrm{cm}^{3}\right)\end{array}$} & \multicolumn{5}{c}{ Surface Energy Components $\left(\mathrm{mJ} / \mathrm{m}^{2}\right)$} \\
\cline { 2 - 6 } & $\gamma_{S}$ & $\gamma_{S}^{L W}$ & $\gamma_{S}^{A B}$ & $\gamma_{S}^{+}$ & $\gamma_{S}^{-}$ \\
\hline 0.80 & 51.60 & 41.80 & 9.80 & 2.86 & 8.41 \\
1.01 & 49.17 & 38.91 & 10.26 & 3.61 & 7.29 \\
1.20 & 46.51 & 36.65 & 9.86 & 4.08 & 5.95 \\
1.39 & 44.96 & 35.75 & 9.21 & 4.08 & 5.20 \\
\hline
\end{tabular}

\subsection{Surface Roughness}

In the scrimber manufacturing process veneer was split along the wood grain to generate a crack-rich structure composed of long and narrow fiber bundles (Figure 3a). When the split veneers (i.e., OWFMs) were laminated into a scrimber panel, the crack-rich structure vanished, and smooth surfaces were achieved. However, random oriented fiber bundles and unavoidable small gaps still existed within the panels. Herein, the surface profiles in two directions (i.e., across and along the grain) (see Figure $3 b$ ) were measured using a stylus system after pneumatic cleaning, and the roughness values are depicted in Figure 4.

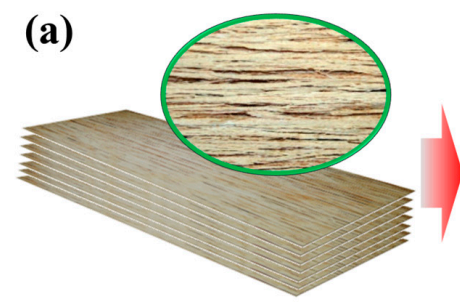

OWFMs

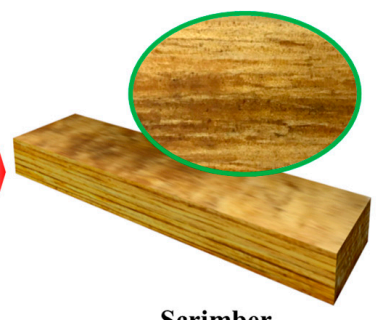

Scrimber

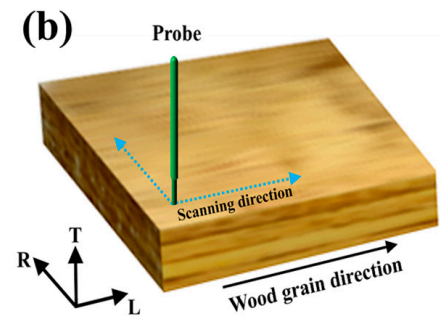

Figure 3. Schematic of (a) scrimber preparation and (b) surface roughness measurement.

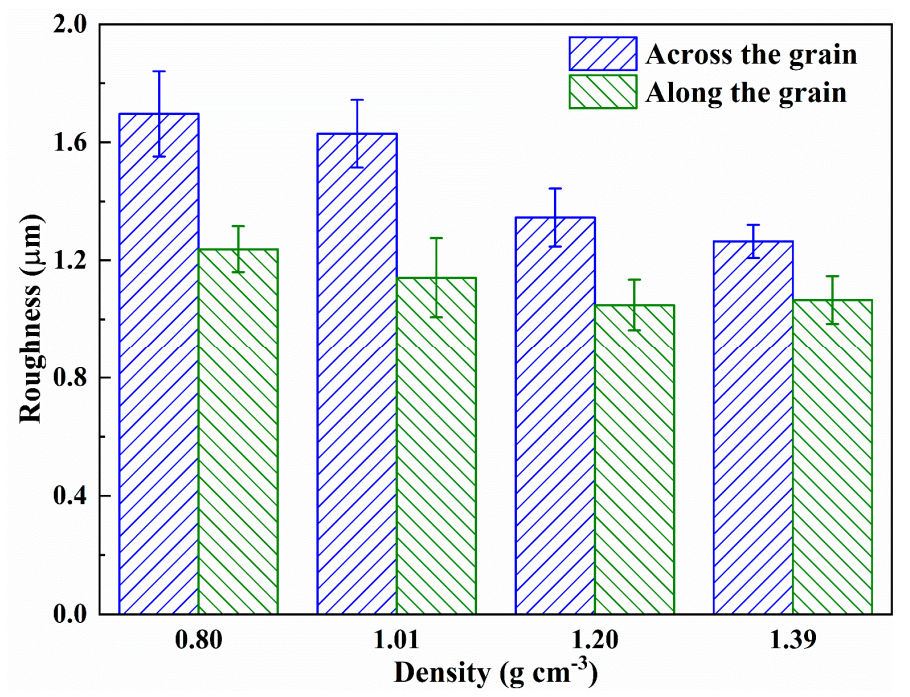

Figure 4. Surface roughness of scrimbers at different densities. 
The average values of $R a$ changed in the small range of 1.0 to $1.7 \mu \mathrm{m}$, and had a gradual reduction with an increase of panel density. For example, the value across the grain at a density of $0.80 \mathrm{~g} / \mathrm{cm}^{3}$ was $1.70 \mu \mathrm{m}$ while that at $1.39 \mathrm{~g} / \mathrm{cm}^{3}$ was $1.24 \mu \mathrm{m}$ (Figure 4). These results demonstrated that high density can remarkably improve the smooth levels of the panel surfaces. According to Wenzel's theory [37,38], low surface roughness typically causes hydrophilic liquids to exhibit poor contact with the surface of wood materials. This is probably the reason that larger contact angles of water appeared on the high-density panels, and the roughness significantly affected the total surface free energy $(p<0.05)$. Moreover, the $R a$ values across the grain were higher than that along the grain. The same phenomenon has been found by Sulaimun et al. when they studied sanded rubberwood surfaces [39]. They found that the measuring direction on the radial surface had a significant influence on roughness, which was due to the orientation of wood cells on the surface. By the ANOVA analysis (not shown), it was found that both density and measuring direction had a significant relationship with roughness $(p<0.05)$.

\subsection{Surface Morphology}

No major defects due to sanding were observed on the panel surfaces at a macroscopic level. However, cell wall damage was found on the microscopic surfaces. Figure 5 shows SEM micrographs of sanded surfaces of scrimbers with varying density. For the low-density panel (Figure 5a), the cell walls and/or microfibers were torn out from the surface and thus irregular grooves were formed, leading to a rough surface. As to the high-density scrimber, most cell walls on the surface broke up and turned into fine particles. The particles filled the lumens and grooves, resulting in a relatively smooth surface (Figure 5d). This finding is in agreement with the results of the study on surface roughness.

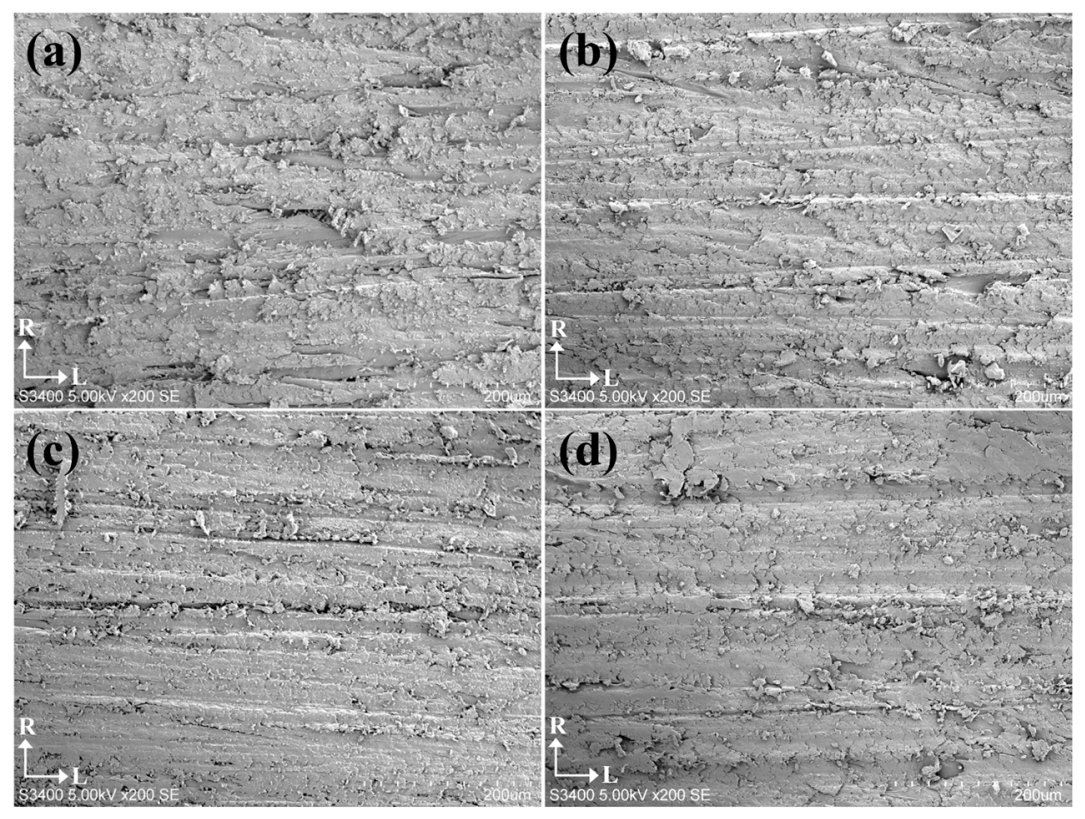

Figure 5. Surface micrographs of the sanded scrimbers with various densities: (a) 0.80, (b) 1.01, (c) 1.20 and (d) $1.39 \mathrm{~g} / \mathrm{cm}^{3}$.

As also found in the figure, the long grooves existed along the wood grain. When the surface profiles were measured by the stylus system, the probe scanned across from a groove to the adjacent groove, leading to a higher roughness. In contrast, a lower roughness was obtained along the grain. These findings explain why the $R a$ values across the grain were higher than that along the grain.

\subsection{Surface XPS Analysis}

Apart from surface morphology, surface chemistry also changed with panel density. As seen from the XPS survey spectra in Figure 6, there were two major elements, carbon $(\mathrm{C})$ and oxygen $(\mathrm{O})$, on 
the surface, and the corresponding peaks occurred at 284 and $532 \mathrm{eV}$. The oxygen-to-carbon $(\mathrm{O} / \mathrm{C})$ atomic ratio was used to detect the change of chemical composition on the scrimber [40,41]. As seen from Table 2, the scrimber surface had a lower $\mathrm{O} / \mathrm{C}$ ratio in comparison with pine wood. The $\mathrm{O} / \mathrm{C}$ ratio of pine wood was 0.54 , and the ratios of the resin and extractive are approximately 0.27 and 0.10 , respectively [42]. These indicated the presence of PF resin and extractive on the panel surface. As the panel density increased, the loading pressure increased during the hot-pressing, and thus more resin was transferred from the interior to the surface. This resulted in a lower $\mathrm{O} / \mathrm{C}$ ratio for high-density panels. The hydrocarbon-rich wood extractive and PF resin are hydrophobic $[43,44]$, thus the scrimber surface repelled water. This contributed to the low surface wettability of high-density scrimber.

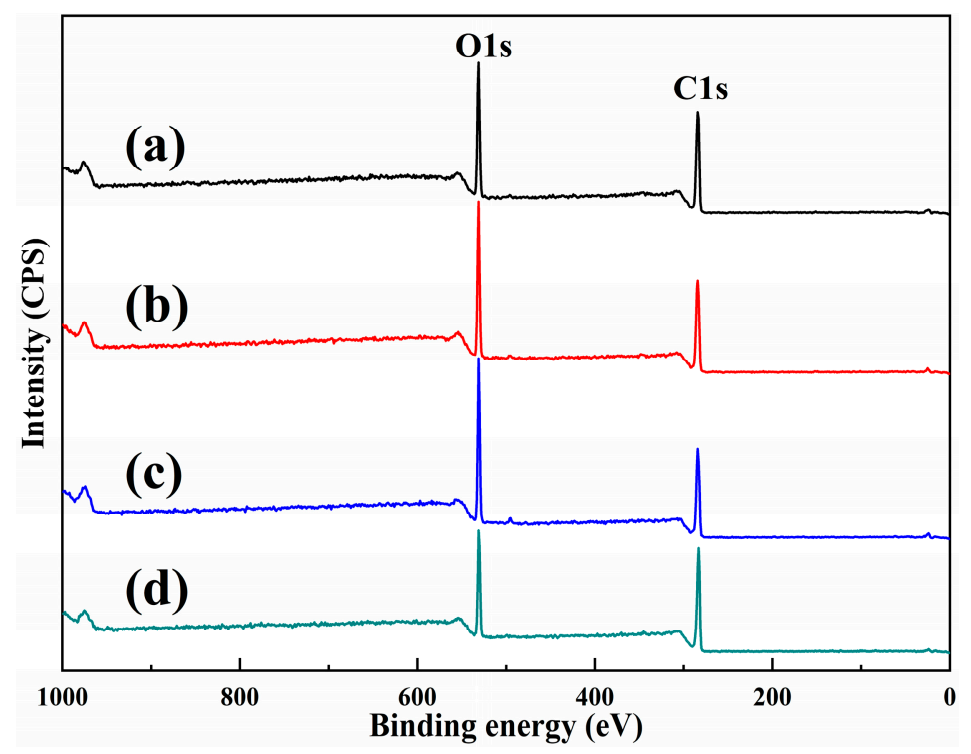

Figure 6. X-ray photoelectron spectroscopy (XPS) spectra of scrimbers with densities of (a) 0.80, (b) 1.01, (c) 1.20 and $(\mathbf{d}) 1.39 \mathrm{~g} / \mathrm{cm}^{3}$.

Table 2. Components of $\mathrm{C} 1 s$ and $\mathrm{O} 1 s$ on the scrimber surfaces.

\begin{tabular}{ccccccc}
\hline \multirow{2}{*}{ Sample } & \multirow{2}{*}{$\mathbf{O} / \mathbf{C}$} & $\mathbf{C}_{\mathbf{o x}} / \mathbf{C}_{\mathbf{u n o x}}$ & \multicolumn{4}{c}{ Component (\%) } \\
\cline { 4 - 7 } & & & $\mathbf{C}_{\mathbf{1}}$ & $\mathbf{C}_{\mathbf{2}}$ & $\mathbf{C}_{\mathbf{3}}$ & $\mathbf{C}_{\mathbf{4}}$ \\
\hline Pine wood & 0.54 & 1.29 & 43.72 & 29.56 & 24.53 & 2.19 \\
Panel 0.80 & 0.53 & 1.06 & 48.62 & 40.85 & 8.46 & 2.07 \\
Panel 1.01 & 0.52 & 0.96 & 50.98 & 39.77 & 7.94 & 1.31 \\
Panel 1.20 & 0.49 & 0.92 & 51.99 & 38.83 & 7.47 & 1.71 \\
Panel 1.39 & 0.40 & 0.53 & 65.21 & 24.55 & 8.80 & 1.43 \\
\hline \multicolumn{7}{c}{${ }^{1}$ The number is the panel density. }
\end{tabular}

To further understand the change of atomic composition on the scrimber surface, the high-resolution spectra of XPS C1s are presented with their deconvolution into four components in Figure 7. Their corresponding quantifications are listed in Table 2. The $\mathrm{C}_{1}$ (related to $\mathrm{C}-\mathrm{C} / \mathrm{C}-\mathrm{H}$ groups) and $\mathrm{C}_{2}$ (related to $\mathrm{C}-\mathrm{O}$ groups) were the main components on the scrimber surfaces, and the sum of both of them accounted for approximately $90 \%$ of the total C content. The $C_{1}$ content increased as the panel density increased, whereas the $C_{2}$ content declined. These changes were attributed to an increase of $\mathrm{PF}$ resin and extractives on the surface [45]. An oxygenated to unoxygenated carbon ratio $\left(C_{o x} / C_{u n o x}\right)$ was calculated using the equation: $C_{o x} / C_{u n o x}=\left(C_{2}+C_{3}+C_{4}\right) / C_{1}$ [46]. The results showed the same trend with the $\mathrm{O} / \mathrm{C}$ ratio in Table 2 . The decrease in total oxygenated carbon bonds suggested that an incremental inactivation occurred on the panels during hot pressing, which partly contributed to the low wettability of scrimber panels, particularly at high density. 

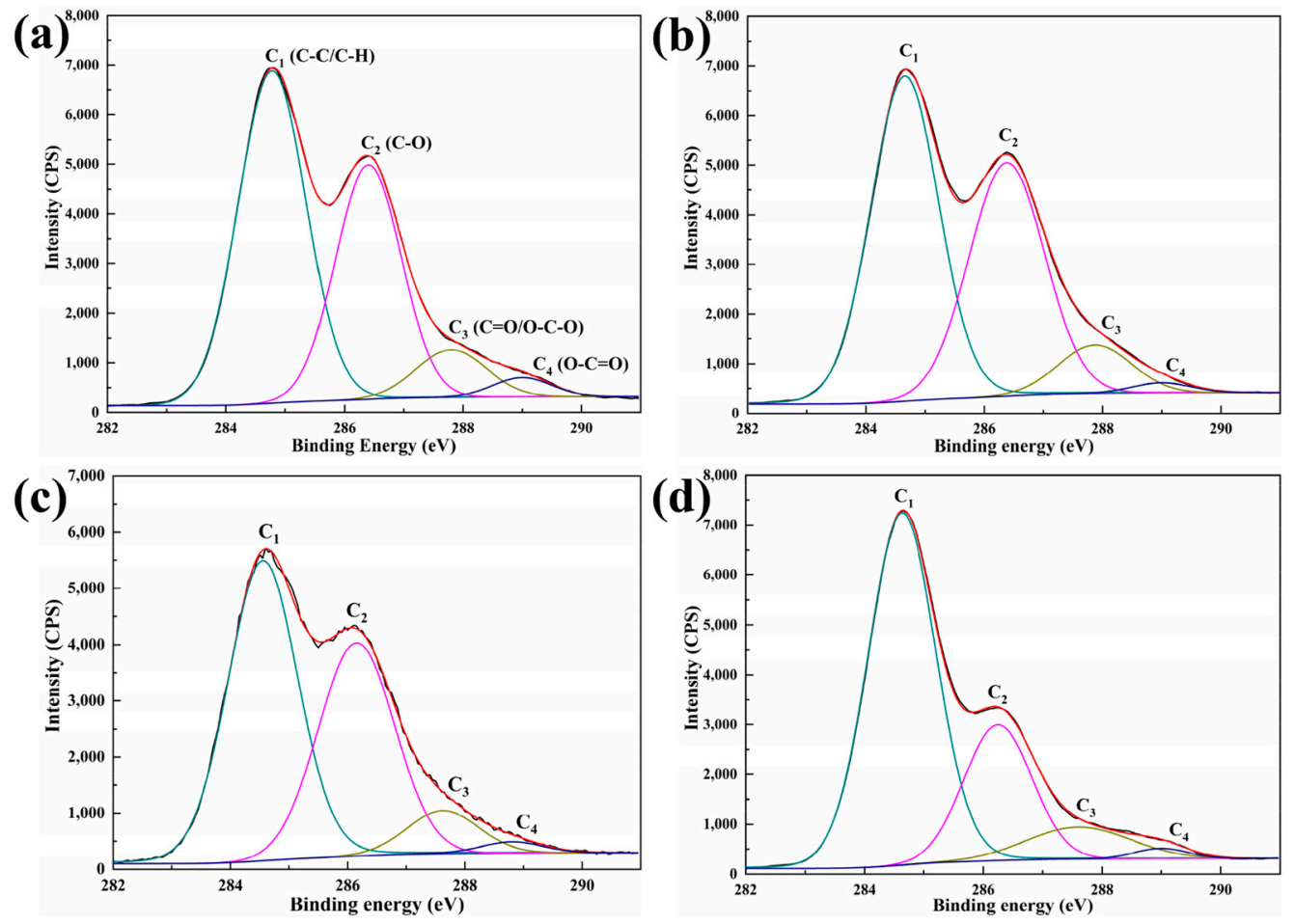

Figure 7. C1s spectra of scrimbers with varying density: (a) 0.80, (b) 1.01 , (c) 1.20 and (d) $1.39 \mathrm{~g} / \mathrm{cm}^{3}$.

\section{Conclusions}

In this study, the surface wettability of pine scrimbers were investigated as well as surface morphology, roughness, and compositions. Results revealed that the scrimber surface is hydrophilic. Increasing panel density led to a reduction of hydrophilicity as well as surface free energy. The surface roughness decreased as the density increased, and the $R a$ values along the grain were much smaller than that across the grain. The long grooves derived from damaged cell walls, gradually disappeared as the panel density increased. There existed few oxygen-containing groups on the high-density panel surfaces. The reductions of both surface roughness and oxygen-containing groups contributed to low wettability of scrimbers, particularly at high panel density. Therefore, the density was an important factor affecting scrimber surface properties. When designing coatings for scrimbers, panel density should take into consideration.

Author Contributions: Formal Analysis, J.W.; Investigation, J.W., Q.L. and Y.Z.; Supervision, W.Y.; Writing-Original Draft, J.W.; Writing-Review and Editing, C.-Y.H. and T.S.

Funding: This work was funded by the National Key R\&D Program of China (No.2017YFD0601205), Special Funds for Basic Research and Operating Expenses of Central Level Public Welfare Scientific Research Institutes (CAFYBB2018SY031), and China Scholarship Council.

Acknowledgments: The authors would like to thank Yue Qi and Yuxiang Huang for technical support and Dynea Guangdong Co., Ltd. for providing phenol-formaldehyde (PF) resin used for the experiment.

Conflicts of Interest: The authors declare no conflict of interest.

\section{References}

1. Coleman, J. A "Reconsolidated" Wood for Structural Purposes; Division of Chem Tech CSIRO: Melbourne, Australia, 1981; pp. 1-10.

2. Kollmann, F.F.; Kuenzi, E.W.; Stamm, A.J. Principles of Wood Science and Technology: II Wood Based Materials; Springer Science \& Business Media: Cham, Switzerland, 2012.

3. Joščák, T.; Müller, U.; Linz, A.; Mauritz, R.; Teischinger, A. Production and material performance of long-strand wood composites. Wood Res. 2006, 51, 37-50. 
4. He, M.; Tao, D.; Li, Z.; Li, M. Mechanical behavior of dowel-type joints made of wood scrimber composite. Materials 2016, 9, 581. [CrossRef] [PubMed]

5. Zhang, Y.; Zhang, Y.; Yu, Y.; Yu, W. Scrimber board (SB) manufacturing by a new method and characterization of SB's mechanical properties and dimensional stability. Holzforschung 2018, 72, 283-289. [CrossRef]

6. Wei, Y.; Rao, F.; Yu, Y.; Huang, Y.; Yu, W. Fabrication and performance evaluation of a novel laminated veneer lumber (LVL) made from hybrid poplar. Eur. J. Wood Wood Prod. 2019, 77, 381-391. [CrossRef]

7. Zhang, Y.; Qi, Y.; Huang, Y.; Yu, Y.; Liang, Y.; Yu, W. Influence of veneer thickness, mat formation and resin content on some properties of novel poplar scrimbers. Holzforschung 2018, 72, 673-680. [CrossRef]

8. Yalinkiliç, M.K.; Ilhan, R.; Imamura, Y.; Takahashi, M.; Demirci, Z.; Yalmkiliç, A.C.; Peker, H. Weathering durability of CCB-impregnated wood for clear varnish coatings. J. Wood Sci. 1999, 45, 502-514. [CrossRef]

9. Pánek, M.; Dvořák, O.; Oberhofnerová, E.; Šimůnková, K.; Zeidler, A. Effectiveness of two different hydrophobic topcoats for increasing of durability of exterior coating systems on oak wood. Coatings 2019, 9, 280. [CrossRef]

10. Xu, J.; Liu, R.; Wu, H.; Qiu, H.; Yu, Y.; Long, L. Coating performance of water-based polyurethane-acrylate coating on bamboo/bamboo scrimber substrates. Adv. Polym. Technol. 2019, 2019, 4264701. [CrossRef]

11. Kúdela, J.; Liptáková, E. Adhesion of coating materials to wood. J. Adhes. Sci. Technol. 2006, 20, 875-895. [CrossRef]

12. Wulf, M.; Netuschil, P.; Hora, G.; Schmich, P.; Cammenga, H. Investigation of the wetting characteristics of medium density fibreboards (MDF) by means of contact angle measurements. Holz als Roh-und Werkstoff 1997, 55, 331-335. [CrossRef]

13. Petrič, M.; Knehtl, B.; Krause, A.; Militz, H.; Pavlič, M.; Pétrissans, M.; Rapp, A.; Tomažič, M.; Welzbacher, C.; Gérardin, P. Wettability of waterborne coatings on chemically and thermally modified pine wood. J. Coat. Technol. Res. 2007, 4, 203-206. [CrossRef]

14. De Moura, L.F.; Hernández, R.E. Evaluation of varnish coating performance for two surfacing methods on sugar maple wood. Wood Fiber Sci. 2007, 37, 355-366.

15. Gavrilovic-Grmusa, I.; Dunky, M.; Miljkovic, J.; Djiporovic-Momcilovic, M. Influence of the viscosity of UF resins on the radial and tangential penetration into poplar wood and on the shear strength of adhesive joints. Holzforschung 2012, 66, 849-856. [CrossRef]

16. Fang, Q.; Cui, H.-W.; Du, G.-B. Surface wettability, surface free energy, and surface adhesion of microwave plasma-treated Pinus yunnanensis wood. Wood Sci. Technol. 2016, 50, 285-296. [CrossRef]

17. Feng, L.; Zhang, Z.; Mai, Z.; Ma, Y.; Liu, B.; Jiang, L.; Zhu, D. A super-hydrophobic and super-oleophilic coating mesh film for the separation of oil and water. Angewandte Chemie 2004, 116, 2046-2048. [CrossRef]

18. Chen, Z.; Li, F.; Hao, L.; Chen, A.; Kong, Y. One-step electrodeposition process to fabricate cathodic superhydrophobic surface. Appl. Surf. Sci. 2011, 258, 1395-1398. [CrossRef]

19. Wenzel, R. Resistance of solid surfaces to wetting by water. Ind. Eng. Chem. 1936, 28, 988-994. [CrossRef]

20. Huang, Y.; Qi, Y.; Zhang, Y.; Zhu, R.; Zhang, Y.; Yu, W. Surface properties of novel wood-based reinforced composites manufactured from crushed veneers and phenolic resins. Maderas Ciencia Tecnología Construction AHEAD 2019, 21, 185-196. [CrossRef]

21. Cool, J.; Hernández, R.E. Improving the sanding process of black spruce wood for surface quality and water-based coating adhesion. For. Prod. J. 2011, 61, 372-380. [CrossRef]

22. Stehr, M.; Gardner, D.J.; Wålinder, M.E. Dynamic wettability of different machined wood surfaces. J. Adhes. 2001, 76, 185-200. [CrossRef]

23. Akbulut, T.; Ayrilmis, N.J.S.F. Effect of compression wood on surface roughness and surface absorption of medium density fiberboard. Silva Fennica 2006, 40, 161-167. [CrossRef]

24. Bao, M.; Huang, X.; Zhang, Y.; Yu, W.; Yu, Y. Effect of density on the hygroscopicity and surface characteristics of hybrid poplar compreg. J. Wood Sci. 2016, 62, 441-451. [CrossRef]

25. Priadi, T.; Hiziroglu, S. Characterization of heat-treated wood species. Mater. Des. 2013, 49, 575-582. [CrossRef]

26. Poletto, M.; Zattera, A.J.; Forte, M.M.; Santana, R.M. Thermal decomposition of wood: Influence of wood components and cellulose crystallite size. Bioresour. Technol. 2012, 109, 148-153. [CrossRef] [PubMed]

27. Patachia, S.; Croitoru, C.; Friedrich, C. Effect of UV exposure on the surface chemistry of wood veneers treated with ionic liquids. Appl. Surf. Sci. 2012, 258, 6723-6729. [CrossRef]

28. Shi, S.Q.; Gardner, D.J. Dynamic adhesive wettability of wood. Wood Fiber Sci. 2007, 33, 58-68. 
29. Croitoru, C.; Spirchez, C.; Lunguleasa, A.; Cristea, D.; Roata, I.C.; Pop, M.A.; Bedo, T.; Stanciu, E.M.; Pascu, A. Surface properties of thermally treated composite wood panels. Appl. Surf. Sci. 2018, 438, 114-126. [CrossRef]

30. Popescu, C.-M.; Tibirna, C.-M.; Vasile, C. XPS characterization of naturally aged wood. Appl. Surf. Sci. 2009, 256, 1355-1360. [CrossRef]

31. Liu, F.P.; Gardner, D.J.; Wolcott, M.P. A model for the description of polymer surface dynamic behavior 1. Contact angle vs polymer surface properties. Langmuir 1995, 11, 2674-2681. [CrossRef]

32. Mantanis, G.; Young, R. Wetting of wood. Wood Sci. Technol. 1997, 31, 339-353. [CrossRef]

33. Owens, D.K.; Wendt, R. Estimation of the surface free energy of polymers. J. Appl. Polym. Sci. 1969, 13, 1741-1747. [CrossRef]

34. Odrášková, M.; Zahoranová, A.; Tiňo, R.; Černák, M. Plasma activation of wood surface by diffuse coplanar surface barrier discharge. Plasma Chem. Plasma Process. 2008, 28, 203-211. [CrossRef]

35. Garnier, G.; Glasser, W.G. Measuring the surface energies of spherical cellulose beads by inverse gas chromatography. Polym. Eng. Sci. 1996, 36, 885-894. [CrossRef]

36. Unsal, O.; Candan, Z.; Buyuksari, U.; Korkut, S.; Babiak, M. Effects of thermal modification on surface characteristics of OSB panels. Wood Res. 2010, 55, 51-58.

37. Prabhu, K.N.; Fernades, P.; Kumar, G. Effect of substrate surface roughness on wetting behaviour of vegetable oils. Mater. Des. 2009, 30, 297-305. [CrossRef]

38. Wenzel, R.N. Surface roughness and contact angle. J. Phys. Chem. 1949, 53, 1466-1467. [CrossRef]

39. Sulaiman, O.; Hashim, R.; Subari, K.; Liang, C. Effect of sanding on surface roughness of rubberwood. J. Mater. Process. Technol. 2009, 209, 3949-3955. [CrossRef]

40. Inari, G.N.; Petrissans, M.; Lambert, J.; Ehrhardt, J.J.; Gérardin, P. XPS characterization of wood chemical composition after heat-treatment. Surf. Interface Anal. 2006, 38, 1336-1342. [CrossRef]

41. Meng, F.-D.; Yu, Y.-L.; Zhang, Y.-M.; Yu, W.-J.; Gao, J.-M. Surface chemical composition analysis of heat-treated bamboo. Appl. Surf. Sci. 2016, 371, 383-390. [CrossRef]

42. Hon, D.N.S. ESCA study of oxidized wood surfaces. J. Appl. Polym. Sci. 1984, 29, 2777-2784. [CrossRef]

43. Martino, C.J.; Shrauti, S.; Banerjee, S.; Otwell, L.P.; Price, E.W. Flake drying temperature affects mat properties during pressing. Holzforschung 2002, 56, 558-562. [CrossRef]

44. Yu, Y.; Liu, R.; Huang, Y.; Meng, F.; Yu, W. Preparation, physical, mechanical, and interfacial morphological properties of engineered bamboo scrimber. Constr. Build. Mater. 2017, 157, 1032-1039. [CrossRef]

45. Börås, L.; Gatenholm, P. Surface composition and morphology of CTMP fibers. Holzforschung 1999, 53, 188-194. [CrossRef]

46. Stark, N.M.; Matuana, L.M.J.P.D. Characterization of weathered wood-plastic composite surfaces using FTIR spectroscopy, contact angle, and XPS. Polym. Degrad. Stab. 2007, 92, 1883-1890. [CrossRef] 